\title{
CLIMATE CHANGE IMPACTS ON AGRICULTURAL WATER MANAGEMENT: CHALLENGE FOR INCREASING CROP PRODUCTIVITY IN SERBIA
}

\author{
Sonja Đuričin ${ }^{1}$, Slađana Savić2 ${ }^{2}$ Duško Bodroža ${ }^{3}$, Gorica Cvijanović4 ${ }^{4}$ Slaviša Đorđevićc
}

\begin{abstract}
Summary
Years which are encompassed by the research, according to the mean daily air temperatures and precipitation, were characterized by the frequent occurrence of extremely warm and dry vegetation periods. The aim of the research is to estimate the economic viability of the production of maize, potatoes and tomatoes in terms of FI (full irrigation). The assessment of the economic viability of the application of the irrigation system when it comes to maize and potato production is done on the basis of a comparative analysis of the realized profit in the natural water regime and FI, whereas in the case of greenhouse tomato production it is done on the basis of comparative analysis of profit achieved in terms of RDI (regulated deficit irrigation) and FI. The research results indicate a positive economic effect of the irrigation system implementation because in our climate the water needs of a culture cannot be satisfied solely by precipitation, and thus water deficit occurs. This lack of rainfall causes yield reduction because it is the main parameter which increases the production profitability. Therefore, increasing the area under irrigation is very important.
\end{abstract}

Key words: climate change, crop productivity, potato, tomato, maize.

JEL: $Q 25$

1 Sonja Đuričin Ph.D., Research Associate, Institute of Economic Sciences, Zmaj Jovina street no. 12, 11000 Belgrade, Serbia, Phone: +381 63843 8896, E-mail: sonja.djuricin@ien.bg.ac.rs

2 Slađana Savić Ph.D., Associate professor, John Naisbitt University Belgrade, Faculty of biofarming, Maršala Tita street no. 39, 24300 Bačka Topola, Serbia, Phone:

+3816044346 15, E-mail: bonita.sladja@gmail.com.

3 Duško Bodroža Ph.D., Research Assistant, Institute of Economic Sciences, Zmaj Jovina street no. 12, 11000 Belgrade, Serbia, Phone: +381 64514 7136, E-mail: dusko.bodroza@ien.bg.ac.rs.

4 Gorica Cvijanović Ph.D., Full professor, John Naisbitt University Belgrade, Faculty of biofarming, Bačka Topola, 24300 Bačka Topola, Maršala Tita street no. 39, Serbia, Phone: +381692406036, E-mail: cvijagor@yahoo.com.

5 Slaviša Đorđević, research assistant, University of Belgrade, Faculty of Agriculture, Belgrade, Zemun, Nemanjina street no. 6, Serbia, Phone: +381 621120 447, E-mail: djslavisa@agrif.bg.ac.rs.

EP 2016 (63) 4 (1333-1346) 


\section{Introduction}

Climate change scenarios for Europe are that global warming resulting from anthropogenic greenhouse gas emissions will lead to substantial temperature increases in Northern Europe during winter and in Southern Europe during summer. The precipitation will increase in Northern Europe and decrease in South-East European and Mediterranean areas, while the predictions are that the number of extreme events, including heat waves, storms and flooding effects will increase in a whole Europe (Beniston et al., 2007; IPCC, 2007). The predictions are also that climate will be continually changing at a relatively rapid rate during this century.

Extreme climate changes have varying impacts on regional ecosystems, agriculture, and health in many European countries. The extremes in temperature and rainfall usually affected crop yields, crop pests, pasture productivity, and create conditions for hazardous fire and health food products, damaged agricultural infrastructure and crops, and wash away productive topsoil. In general, these events resulted in increased volatility in agricultural production and commodity prices, as well as higher costs for food transport, infrastructure repair, and public health services (FAO, 2011).

The sensitivity of Europe agriculture to climate change, especially drought, has a distinct north-south gradient and many studies indicating that Southern Europe will be more severely affected than Northern Europe. In a lot of the countries of these regions, economic development is heavily dependent upon growth in the agriculture and, therefore, the climate change impacts on agriculture could have significant social consequences (EEA, 2008). In Northern Europe increases in productivity and expansion of suitable cropping areas are expected to dominate, whereas the disadvantages from increases in water shortage and drought will dominate in Southern Europe. The increased crop productivity in Northern Europe will be also caused by lengthening growing season, decreasing cold effects on crop growth and extension of the frost-free period. On the contrary, the expected decrease in productivity in Southern Europe will be the consequence of the shortening of the growing period, with subsequent negative effects on grain filling (Iglesias et al., 2009).

In the areas of increased drought and high temperature, the irrigation is necessary for successful agricultural production. Currently, due to the climate change impacts many countries are faced with the increased competitions for water resources between different sectors (agriculture, industry or domestic consumption). Therefore, saving water resources and increasing crop productivity per unit of water ("more crop per drop") is becoming of strategic importance for many countries (Luquet et al., 2005). This is not an easy task because crops and vegetables requires lots of water for producing optimal yield. Yields of maize in the region vary significantly from year to year in a very wide range depending on the amount and distribution of rainfall in the growing corn. Average value corn water needs are about $450 \mathrm{~mm}$, so that during the corn growing season average lack of precipitation is 150 to $250 \mathrm{~mm}$. Various studies have shown that irrigation has a significant effect on the yield of maize and that it can significantly increase (Josipovic et al., 2014; Kusce et al., 2013). As for the production of potato in the Vojvodina conditions of the required amount of water to potato production medium late and late varieties successful, ranges from 460- 
$480 \mathrm{~mm}$ (rainfall + irrigation), while, when it comes to the production of early potatoes that need $260-280 \mathrm{~mm}$ (Ilin, 2000). Depending on the year, amount and distribution of rainfall and temperature conditions in this area there is a deficit of rainfall of $120-200 \mathrm{~mm}$ in the production of physiologically mature tubers and about $40 \mathrm{~mm}$ in the production of early potatoes. The difference between the needs of plants and the amount of water that comes through the rain we can catch up with three to five irrigations in the production of physiologically ripe potatoes and one in the production of early potatoes. In the mountainous area of western Serbia because of lower temperatures and higher precipitation amounts indicated deficits are less pronounced, but here arises from the lack of moisture 50-120 $\mathrm{mm}$. The application of irrigation in our conditions, it is possible to increase the average potato yield about 40-45\%. Total needs for water after tomato transplanting are 400-600 $\mathrm{mm}$, in Vojvodina slightly less around $450-520 \mathrm{~mm}$, so that the average daily consumption of around 3.6 to $4.5 \mathrm{~mm}$, a max. $8 \mathrm{~mm} \cdot$ day $^{-1}$. The consequences of a water deficit can have on crop yield also depends on the stage of development the crop plants themselves. Plants are differently sensitive to rainfall deficit in various stages of development. Corn is the most sensitive during the flowering and grain filling, potato during the tuber initiation and enlargement, while the most susceptible tomato during the flowering, fruit setting and enlargement (Jovanović, Stikić, 2012). Therefore, the significant effort is made to develop new crop varieties more tolerant to drought and high temperature and to the achievement of economically profitable production by irrigation (Jovanović, Stikić, 2012). Currently, optimal and profitable irrigation are based on the on the use new irrigation methods (as deficit irrigation methods) and the use of high technologies (as infrared thermography) for irrigation scheduling (Petrovic et al., 2016).

In Serbia, similar to other less developed countries, only a small proportion of the arable land (only 3.7\%) is equipped for irrigation (Kresović et al., 2014). Furthermore, the new water saving irrigation methods and approaches are not in the use. Another problem is that little attention is paid to the quality of the irrigation water. Very often available water sources are subjected to contamination by sewage discharge from small communities, cattle feedlot drainage, grazing animals along irrigation canals, embankments, stormwater events etc. Because irrigation channels are frequently small, these changes in pollution discharges can result in rapid deterioration of water quality and starting point of a water-soil-plant-food contamination pathway (Forslund et al., 2010; Surdyk et al., 2010). The pathogens, organic and inorganic chemical compounds in wastewater, can induce health risks for workers and consumers, exposed via the direct or indirect contact with such waters during field work and ingestion of fresh and processed food (PeraltaVidea et al., 2009).

Currently, the agricultural water management in Serbia has to meet several challenges: to increase the irrigation areas, optimally use available water resources and to produce high quality food and food products. The importance and contribution of agriculture to overall economic development can be seen through its participation in the gross domestic product, exports and employment (Vukelic, Đuričin, 2012). The high degree of dependence of agricultural production on climate is a reflection of the low level of its development, and a 
lack of investment in more intensive irrigation system exploitation causes the occurrence of drastically lower yield which reflects negatively on the contribution of this sector to overall economic development of the country.

In the last three years, the share of agriculture in GDP (Gross Domestic Product) is $8.17 \%$, on average, which is far lower than the European average. In fact, only $5 \%$ of EU agricultural population participates $15 \%$ in this community's GDP, while in Serbia, more than twice as bigger agricultural population participates in the creation of nearly half the value of the previously mentioned GDP (Ibid., P. 618). Although in comparison to the Western Balkan countries, where the share of agriculture and food industry in the total exports is only $10 \%$, Serbia has a much more favorable position, it still does not exploit its total export potential. In Western Europe, the share of agriculture is $40 \%$ of total exports, on average, which is nearly 8 times more than the share of agriculture without the food industry in the total exports of the Republic of Serbia (Đuričin, Beraha, 2013). On the other hand, the share of agriculture in total employment exceeds $20 \%$, and thus it is one of the most promising sectors for absorbing long-standing disorders present in the labor market. Despite a long tradition, knowledge and available natural resources, the stimulating economic measures, which would allow more intense and competitive agricultural production, remain absent. With a view of projection that agricultural production in Serbia will be faced with a more stressful and uncertain environment caused by climate change, and especially drought, the aim of the presented paper was to assess the economic impact and profitability of irrigation of most important crops in Serbia. The assessment of the economic viability of the FI application was tested on maize, potato and tomato production. Maize was elected as an important cash crop, potatoes and tomatoes as important vegetable crops, with the difference that the potatoes are exclusively produced in the open field and tomatoes are grown mostly in greenhouses.

\section{Material and method}

Assessment of the cost-effectiveness of the irrigation system application in the case of the production of maize, potatoes and tomatoes was carried out based on the amount of the realized profit (Perez-Perez et al., 2010; Stikic et al., 2011), which reflects a net economic benefit calculated as the difference between the total revenues and total expenditures of production (Younis et al., 1991; Kendall et al., 2007; MH ABD EL-WAHEDA, ALI, 2013). In order to assess the commercial viability of the irrigation system application in the case of the maize and potato production, a comparative analysis of the realized profit in the natural water regime and FI was made, while due to the greenhouse tomato production a comparative analysis of the profit achieved in terms of RDI and FI was made.

Revenues collected from the production of maize and potatoes in the natural water regime and tomatoes in the RDI conditions are calculated as the product of the average yield of these crops and their average ruling market price, while total expenses are equal to the average value of production costs, which include costs of implemented agricultural practices characteristic for the production of certain culture. For the purposes of the calculation of profit, in the case of FI, the value of revenue is increased by the growth in yield. Also, the amount of expenditure was increased based on the occurrence of the variable costs incurred 
as a result of the application of different irrigation systems. In the case of maize production for irrigation purposes tifon A-82/300, the sprinkler Rain Bird SR 103 EM, was used (Kresović et al., 2014), while during the potato irrigation the sprinkler irrigation was used (Matović et al., 2016). For the purposes of tomato irrigation in terms of reduced irrigation (RDI) and FI the drop by drop system was used (Savić et al., 2011).

Profit in the natural water regime $=(a \cdot b)-d$

Profit in the case of irrigation system application $=\left(\left(\frac{a \cdot c}{100}+a\right) \cdot b\right)-\left(\frac{d \cdot \theta}{100}+d\right)$ $\left(\left(\frac{a \cdot c}{100}+a\right) \cdot b\right)-\left(\frac{d \cdot e}{100}+d\right)$

The meaning of symbols:

$\mathrm{a}=$ The average yield in the natural water regime

$\mathrm{b}=$ Average purchase price per year

$\mathrm{c}=$ The average yield increases due to irrigation

$\mathrm{d}=$ The average production cost in the natural water regime

$\mathrm{e}=$ The average increase in production costs due to irrigation

Data required for the calculation of profits is collected from existing studies dealing with assessment of the economic viability of the production of maize, potatoes and tomatoes when different irrigation systems are applied (Kresović et al., 2014; Matovic et al., 2016; Savić et al., 2011). Based on current research, for the purpose of calculation of profits, data was collected on the amount of the ruling purchase market prices, the average value of yield and the cost of production in the natural water regime conditions in the case of the production of maize and potatoes, or in terms of reduced irrigation in the case of tomato production. Also, the data necessary to calculate the average percentage increase in yield and the production costs of maize, potatoes and tomatoes in the case of FI was collected based on the existing research.

Table 1. Parameters for the calculation of profit in rainfed conditions, RDI and FI

\begin{tabular}{|l|c|c|c|c|c|}
\hline Plant & $\begin{array}{c}\text { The average } \\
\text { yield in } \\
\text { rainfed } \\
\text { conditions } \\
\left(\mathbf{t} \cdot \mathbf{h a} \mathbf{H}^{-1}\right)\end{array}$ & $\begin{array}{c}\text { Average } \\
\text { purchase } \\
\text { price per } \\
\text { year } \boldsymbol{\epsilon} \cdot \mathbf{k g}^{-1}\end{array}$ & $\begin{array}{c}\text { The average } \\
\text { yield } \\
\text { increases in } \\
\text { the FI } \mathbf{( \% )}\end{array}$ & $\begin{array}{c}\text { Average cost of } \\
\text { production in } \\
\text { rainfed condition } \\
\left(\boldsymbol{\epsilon} \cdot \mathbf{h a}^{-1}\right)^{*}\end{array}$ & $\begin{array}{c}\text { The average } \\
\text { increase of } \\
\text { production costs } \\
\text { in FI(\%) }\end{array}$ \\
\hline Maize & 10.46 & 0.11 & 18.70 & 458,20 & 11.29 \\
\hline Potato & 19.00 & 0.20 & 86.00 & $3,068.55$ & 36.30 \\
\hline Tomatoes & 55.90 & 0.54 & 5.55 & $5,281.00$ & 13.67 \\
\hline
\end{tabular}

Source: Kresović et al., 2014; Matović et al., 2016; Savić et al., 2011

* Note: In the case of tomatoes the average yield and average production costs are related to the 
greenhouse production in which we had reduced irrigation techniques RDI. The average increase in yield and production costs is calculated based on the comparative analysis of the results obtained in terms of RDI and FI.

Average values of the parameters required for assessing the economic viability of production of maize hybrid ZP SC 704 (FAO maturity group 700) calculated based on the published results of experimental studies conducted on the experimental field of Maize Research Institute Zemun Polje from 2002 to 2010 (Kresović et al., 2014), while in the case of the potato production, medium-late varieties LAURA, calculated on the basis of the results of the research on the production plot in Guča in the period from 2011 to 2013 (Matović et al., 2016). In the case of the calculation of the average value of the parameters required for assessing the economic viability of tomato production, the findings of research into the possibilities of using techniques of regulted deficit irrigation (RDI) in the greenhouse production of a variety Abellus in the period from 2006 to 2007 were used (Savić et al., 2011). In the Republic of Serbia in terms of natural water supply in case of production of maize and potato yields were on average $10.46 \mathrm{t} \cdot \mathrm{ha}^{-1}$ (Kresovic et al., 2014), $19.00 \mathrm{t} \cdot \mathrm{ha}^{-1}$ (Matović et al., 2016) respectively, and in the case of tomato production, using techniques RDI, 55.90 t.ha-1 (Savić et al., 2011). The average annual purchase price of maize, potatoes and tomatoes amounted to $0.11 € \cdot \mathrm{kg}^{-1}$, $0.20 € \cdot \mathrm{kg}^{-1}$ and $0.54 € \cdot \mathrm{kg}^{-1}$ respectively, while the average cost of production in the natural water regime, in the case of maize and potatoes, amounted to $458.20 € \cdot$ ha $^{-1}$ and 3.068.55 $€ \cdot$ ha $^{-}$ ${ }^{1}$ respectively (Kresovic et al., 2014; Matovic et al., 2016), and RDI, in the case of tomatoes, 5.281.00 $€ \cdot$ ha $^{-1}$ (Savić et al., 2011). The average yield increases of maize and potatoes from the use of irrigation systems amounted to $18.70 \%$ and $86.00 \%$ respectively, while the average increase in production costs amounted to $11.29 \%$ and $36.30 \%$ respectively (Kresovic et al., 2014; Matovic et al., 2016). In the case of tomato production, due to the application of FI in relation to the RDI, the average increase in yield and production costs amounted to $5.55 \%$ and $13.67 \%$ respectively (Savić et al., 2011).

\section{Results and discussion}

Intense rainfall variability, both on an annual basis, and on the basis of vegetation seasons, substantially influences the reduction of yields and profits arising from the production of different cultures. Assessment of the economic benefits of different system applications is particularly important in extremely dry years when the effect of applying the irrigation is the most intensive (Maksimovic et al., 2004). The years in which an analysis and assessment of the economic effects of the application of irrigation system were performed, according to the mean daily air temperatures and the amount of precipitation, were characterized by the frequent occurrence of extremely warm and dry vegetation period. In the period from 2002 to 2010 for which the assessment of the economic viability of the production of maize in FI conditions was carried out according to the amount of rainfall, an extremely arid period was recorded, three very dry and two normal vegetation period (Kresović et al., 2014). This period covers both 2006 and 2007 for which the analysis of the economic viability of greenhouse production of tomatoes in FI conditions was performed, which according to the average daily air temperature belong to the group of warm and extremely warm years (Ibid.). Dry and 
hot vegetative seasons were characteristic for the period from 2011 to 2013 for which the assessment of the economic viability of the production of potatoes was carried out (Matović et al., 2016).

Water use efficiency (WUE) is defined as the ratio obtained yields per unit of evapotranspiration (ET) and depends on environmental conditions and plant species. If the plants are irrigated usually calculated IWUE (irrigation water use efficiency), which represents the ratio obtained yields per unit of water used for irrigation. The value of the efficiency of water use in a different culture is different. WUE in maize is usually between 1.72 and $2.96 \mathrm{~kg} \cdot \mathrm{m}^{-3}$ and it also depends on the amount of water available. WUE depends on the time of year, for example, it in potato varies around 8-9, 6-8 and 11-14 $\mathrm{kg} \mathrm{m}^{-3}$ for the fall, winter and spring, respectively (Nagaz et al., 2007). It also depends on the region where it is grown, and in our country it's range is between 81.23 and $98.21 \mathrm{~kg} \mathrm{ha}^{-1} \mathrm{~mm}^{-1}$ (Aksic et al., 2014). As a parameter of the efficiency of water use in the tomato which is grown mainly in greenhouses usually is used IWUE which is values are depending on growing conditions and genotype. Some of our research has shown that in the tomato hybrids Cedrico and Abellus IWUE values were 47.6 and $47.4 \mathrm{~kg} \mathrm{~m}^{-3} \mathrm{H}_{2} \mathrm{O} \mathrm{ha}^{-1}$ (Savic et al., 2011). In water drought conditions usually values IWUE are increasing while tomato yield is decreasing (Savic et al., 2011). Unprofitable crop production, characteristic primarily for areas with frequent occurrence of extremely warm vegetation periods and the low level of implementation of new production technologies awakened the need for the calculation of the economic viability of the application of different irrigation systems. The results obtained by comparative analysis of average height of realized profit in rainfed condition and FI in the case of the production of maize and potatoes, and the average height of realized profit in RDI and FI in the case of greenhouse production of tomatoes indicate a positive economic effect of the implementation of irrigation systems.

Table 2. Economic analysis of maize, potato and tomato production in FI - in $€ \cdot \mathrm{kg}^{-1}-$

\begin{tabular}{|l|r|r|r|r|r|r|r|}
\hline Plant & $\begin{array}{c}\text { Average } \\
\text { income in } \\
\text { rainfed } \\
\text { condition/RDI } \\
\text { of production } \\
\text { in rainfed } \\
\text { condition/RDI }\end{array}$ & $\begin{array}{c}\text { Average cost } \\
\text { An rainfed } \\
\text { condition/RDI }\end{array}$ & $\begin{array}{c}\text { Average } \\
\text { income } \\
\text { in FI }\end{array}$ & $\begin{array}{c}\text { Average } \\
\text { costs in } \\
\text { FI }\end{array}$ & $\begin{array}{c}\text { The } \\
\text { Average } \\
\text { profit in } \\
\text { FI }\end{array}$ & $\begin{array}{c}\text { difference } \\
\text { in the } \\
\text { realized } \\
\text { profit } \\
\text { rainfed } \\
\text { condition } \\
\text { (RDI) VS } \\
\text { FI }\end{array}$ \\
\hline Maize & 1.151 & 458 & 692 & 1,366 & 510 & 856 & 164 \\
\hline Potato & 3,800 & 3,069 & 731 & 7,068 & 4,182 & 2,886 & 2,155 \\
\hline Tomatoes & 30,186 & 5,281 & 24,905 & 31,860 & 6,003 & 25,857 & 952 \\
\hline
\end{tabular}

Source: Calculation of authors according to the data: Kresović et al., 2014; Matović et al., 2016; 2016; Savić et al., 2011

The positive economic effect in the case of maize production in FI, compared to rainfed condition, amounts to $164 € \cdot \mathrm{kg}^{-1}$ in average, and in the case of potato $2.155 € \cdot \mathrm{kg}^{-1}$. Underutilization of installed capacity for irrigation in maize production in the Republic of Serbia for a period of eleven years has caused the emergence of losses of about 122 million Euros 
(Kresovic et al., 2014), while due to the absence of application of sprinkler irrigation in the process of potato production on a three-year level the country lost $1,985.11 € \cdot \mathrm{kg}^{-1}$ in average (Matović et al., 2016). The occurrence of extremely high losses due to insufficient utilization of existing irrigation systems and lack of investment in their construction, are unjustified especially in terms of the structure of total production expenses in the case of application of FI. Surveys indicate the low share of variable costs in total expenses of production (Kresovic et al., 2014; Matovic et al., 2016), which is largely a result of the continuing low reimbursement for irrigation and electricity prices (Stikic et al., 2011) as well as additionally engaged workforce in case of application of FI (Kresovic et al., 2014).

In comparison with developed countries of Western Europe, in Serbia the price of water for irrigation is up to six times lower (Ibid.). In Spain, depending on the region, the price of water for irrigation ranges from 0.12 to $0.30 € \mathrm{~m}^{-3}$ (Perez-Perez et al., 2010), while in Serbia, in the observed nine years, the same on average costs $0.05 € \mathrm{~m}^{-3}$ (Kresovic et al., 2014). Even if we exclude the comparison with developed countries of Western Europe, in relation to Montenegro, Macedonia and Bosnia and Herzegovina, Serbia has lower price of water by $10 \%, 44 \%$ and $90 \%$ respectively (Stikic et al., 2011). In comparison with developed countries of Western Europe, Serbia has about three times lower cost of electricity (Kresovic et al., 2014; Matovic et al., 2016). The price of electricity in Spain is approximately $0.12 € \mathrm{kWh}^{-1}$ (Perez-Perez et al. 2010), Portugal $0.13 € \mathrm{kWh}^{-1}$ (Rodrigues et al., 2013), while its average value in Serbia is $0.04 € \mathrm{kWh}^{-1}$ (Kresovic et al., 2014). In addition, Serbia has about nine times lower average labor cost per hour in relation to Hungary and Poland (Kresovic et al., 2014; Matovic et al., 2016). Compared to the developed countries of Western Europe, France, Germany and Belgium, where the average wage is about $36 € \cdot \mathrm{h}^{-1}$, Serbia has more than fifty times lower labor costs (Ibid.).

The yield of crops heavily depends on the climate trends, which indicates a low level of investment in irrigation systems as well as a large number of individual small farms which are not able to fund preventive measures and mechanisms for the protection against drought and thus limit more intensive agricultural production (Vukelic, Đuričin, 2012, p. 615). State intervention in the reconstruction of existing and construction of new irrigation systems is necessary because the great number of companies in Serbia is characterized by the absence of their ability to obtain funds spent on work and the objects of labor. The absence of the possibility of independent financing of simple reproduction is the result of years of poor agricultural product trade emerged in response to the import of products for which production the agriculture of the Republic of Serbia has the potential, monopoly on the side of buyers of agricultural products as well as large fluctuations in the volume and quality of production (Vukelic, Đuričin, 2012). Bad parity pricing of agricultural products, with the ruling market conditions of obtaining external sources of financing, calls into question not only the growth and development, but also the survival of enterprises in the agricultural sector. The largest number of farms in the Republic of Serbia is characterized by a low level of technical equipment. The equipment is so poor that only $50 \%$ of farms have their own tractor, and more than $90 \%$ of the total machinery is obsolete, causing losses in yields ranging between 23 and 92 million Euros per year (Eric et al., 2015). Illiquid and unprofitable operations lead the agricultural enterprises to bankruptcy and require the adoption of measures whose 
implementation will cause organized abandonment of outdated production processes and successfully create new value by applying innovative, production technologies supported by market economy (Đuričin et al., 2014).

Increasing the volume of crop production due to the implementation of the irrigation system opens up the possibility of growth in the agricultural sector products' share in the total exports of the country. Higher degree of irrigation system exploitation would improve crop and livestock production, increasing the export potential of the entire agricultural sector. The lack of ability to plan the yield in plant production has a negative impact on the performance of agricultural enterprises engaged in breeding animals. The high variability in the growing of plants that are the main source of food in livestock affected the reduction of the amount of livestock and worsened business performance of enterprises engaged in breeding animals (Đuričin et al., 2013).The increased yield of potatoes due to irrigation would affect the growth of its share in total crop production in Serbia, which is on average 6\% (Vukelic, Djuricin, 2012). Average inflow from export of potatoes is considered low due to the fact that it accounts for only $0.01 \%, 0.18 \%$ and $0.08 \%$ in total exports of the country, exports of agriculture and food production exports, respectively (Matović et al., 2016). The situation is similar when it comes to maize, one of the most important field crops not only in Serbia but also in the world, which in the last three years, in total exports of the country, as maize in grains, contributes only with $3.31 \%$ on average.

Table 3. The positive effects of the application of FI in terms of exports / imports

\begin{tabular}{|c|c|c|c|c|c|c|}
\hline & $\begin{array}{c}\text { Average } \\
\text { amount (t) }\end{array}$ & $\begin{array}{c}\text { The } \\
\text { average } \\
\text { value }(000 \\
€)\end{array}$ & $\begin{array}{c}\text { The average } \\
\text { export price } \\
\left(€ \cdot \mathbf{k g}^{-1}\right)\end{array}$ & $\begin{array}{c}\% \text { Increase } \\
\text { in yield due } \\
\text { FI }\end{array}$ & $\begin{array}{l}\text { Quantity expressed } \\
\text { export growth / } \\
\text { decline in imports } \\
\text { in Fl (t) }\end{array}$ & $\begin{array}{c}\text { The value of } \\
\text { exports reflected } \\
\text { growth / decline } \\
\text { in imports in FI } \\
(000 €) \\
\end{array}$ \\
\hline \multicolumn{7}{|c|}{ Exports } \\
\hline Maize & $1,468,362$ & 279,876 & 0.19 & 18.70 & 274,584 & 52,337 \\
\hline $\begin{array}{l}\text { Potatoes, } \\
\text { fresh or } \\
\text { chilled }\end{array}$ & 11,276 & 1,633 & 0.14 & 86.00 & 9,697 & 1,404 \\
\hline $\begin{array}{l}\text { Tomatoes } \\
\text { fresh or } \\
\text { chilled } \\
\end{array}$ & 5,143 & 1,921 & 0.37 & 5.55 & 285 & 107 \\
\hline \multicolumn{7}{|c|}{ Imports } \\
\hline Maize & 4,183 & 11,617 & 2.78 & 18.70 & 782 & 2,172 \\
\hline $\begin{array}{l}\text { Potatoes, } \\
\text { fresh or } \\
\text { chilled }\end{array}$ & 8,896 & 2,362 & 0.27 & 86.00 & 7,651 & 2,031 \\
\hline $\begin{array}{l}\text { Tomatoes } \\
\text { fresh or } \\
\text { chilled }\end{array}$ & 22,198 & 14,510 & 0.65 & 5.55 & 1,232 & 805 \\
\hline
\end{tabular}

Source: Calculation of authors according to the data of the Statistical Office of the Republic of Serbia

Note: The average amount of quantity, value and the export or the import prices of maize, potatoes and tomatoes, is calculated based on SORS data for the period from 2006 to 2015.

EP 2016 (63) 4 (1333-1346) 
If the rise in yields of maize, potatoes and tomatoes would be used entirely for exporting, the country would secure a significant inflow of funds on this basis. Export growth based on increased quantities of maize production, due to the application FI, would amount to 52.337 thousand Euros, on average, annually; 1.404 thousand Euros in the case of potatoes, and 107 thousand Euros in the case of tomatoes. If the rise in yields, due to the application FI, would be used for domestic consumption, the expenditure on imports of maize annually, on average, would reduce to 2.172 thousand Euros, in the case of potatoes for 2,031 thousand Euros, and tomatoes for 805 thousand Euros.

\section{Conclusion}

The years in which an analysis and assessment of the economic effects of the application of the irrigation system were implemented, are characterized by frequent occurrence of extremely warm and dry vegetation period. The research results point to the positive economic effects of the application of the irrigation system. Positive economic effect in the case of the production of corn and potatoes in FI, compared to rainfed condition, on average amounted to $164 € \cdot$ ha $^{-1}$ and $2.155 € \cdot$ ha $^{-1}$, respectively, in the case of greenhouse production of tomatoes in FI, compared to RDI, in average amount to $952 € \cdot \mathrm{ha}^{-1}$. The key parameter influencing the economic effects of FI in all three tested cultures was an increase in yields.

Observed from the aspect of export growth, economic effect of applying FI annually in the case of maize, on average, amounted to 52.337 thousand Euros, and in the case of potatoes and tomatoes it amounted to 1.404 and 107 Euros, respectively. On the other hand, in terms of imports, the application of FI would provide savings potential that annually in the case of maize, on average, would amount to 2.172 thousand Euros and in the case of potatoes and tomatoes 2.031 and 805 Euros respectively. Positive economic effects of irrigation system implementation are the starting point in the process of revitalization of existing and construction of new irrigation systems. More intensive use of irrigation systems would cause the stabilization and increase in yields, the growth of exports and decrease in imports, which would have a positive effect on the development of the agricultural sector and the entire economy of the Republic of Serbia.

\section{References}

1. Aksic, M., Gudzic, S., Deletic, N., Gudzic, N., Stojkovic, S., Knezevic, J. (2014): Tuber yield and evapotranspiration of potato depending on soil matric potential, Bulgarian Journal of Agricultural Science, Agricultural Academy Bulgaria, vol. 20, no. 1, pp. 122-126.

2. Beniston, M., Stephenson, D.B., Christensen, O.B., Ferro, C.A.T., Frei, C., Goyette, S., Halsnaes, K., Holt, T., Jylhä, K., Koffi, B., Palutikof, J., Schöll, R., Semmler, T., Woth, K. (2007): Future extreme events in European climate: an exploration of regional climate model projections, Climatic Change, Springer, Vol. 81, no. 1, pp. 71-95, Netherlands.

3. Đuričin, S., Bodroža, D. (2013): The impact of drought on yield position of the 
group of enterprises from agriculture sector, Economics of agriculture, pp. 25-39, The Balkan Scientific Association of Agrarian Economists, Institute of Agricultural Economics, Belgrade and Academy of Economic Studies, Bucharest, Romania.

4. Đuričin, S., Beraha, I., Bodroža, D. (2013): The Impact of Climate Extremes on Agricultural Output in the Republic of Serbia, Ecologica, vol. 72, no. 20, pp. 587592, Naučno-stručno društvo za zaštitu životne sredine Republike Srbije.

5. Đuričin, S., Beraha, I., BODROŽA, D. (2014): Troškovi agrarne politike kao indikator održivog poljoprivrednog razvoja, Ecologica, vol. 75, no. 21, pp. 468-472, Naučno-stručno društvo za zaštitu životne sredine Republike Srbije.

6. Đuričin, S., Beraha, I. (2013): Evaluation of Business Performances of Agricultural Enterprises in the Mixed Farming Sub-sector and their Impact on Economic Growth of the Republic of Serbia, Agriculture in Serbia and Portugal: recent developments and economic policy implications, pp. 122-138.

7. EEA (2008): Impacts of Europe's changing climate - 2008 indicator-based assessment, EEA Report no. 4, p. 242, EEA, European Communities, Copenhagen, Denmark.

8. Erić, D., Đuričin, S., Ppantić, O. (2015): Development of SMEs and small farms in agribusiness in Serbia, SMEs and small farms in agribusiness in the Black Sea economic cooperation region, pp. 218-237.

9. FAO (2011): Climate change, water and food security, FAO Water reports, vol. 36, pp. 1-168, FAO, Rome.

10. Forslund,A., Ensink, J.H.J., Battilani, A., Kljujev, I., Gola, S., Raicevic, V., Jovanovic, Z., Stikic, R., Sandei, L., Fletcher, T., Dalsgaard, A. (2010): Faecal contamination andhygiene aspect associated with the use of treated wastewater and canal water for irrigation of potatoes (Solanum tuberosum L.), Agricultural Water Management, Elsevier Ltd., vol. 98, no. 3, pp. 440-450, Amsterdam, Netherlands.

11. Iglesias, A., Garrote, L., Quiroga, S., Moneo, M. (2009): Impacts of climate change in agriculture in Europe, PESETA-Agriculture study, 59, Office for Official Publications of the European Communities, Luxembourg.

12. Ilin, Ž., Đurovka, M., Marković, V. (2000): Agrobiološke osnove za uspešnu proizvodnju krompira, Arhiv za poljoprivredne nauke, vol. 61, pp. 101-113, Savez poljoprivrednih inženjera i tehničara Jugoslavije.

13. IPCC (2007): Climate Change 2007: Impacts, Adaptation, and Vulnerability, Contribution of Working Group II to the Third Assessment Report of the Intergovernmental Panel on Climate Change. M.L. Parry, O.F. Canziani, J.P. Palutikof, P.J. van der Linden \&C.E. Hanson, (Ed.), p. 976, Cambridge University Press, Cambridge, UK. 
14. Josipovic, M, Plavsic, H., Kovacevic, V., Markovic, M., Iljkic, D. (2014): Impacts of irrigation and genotype on yield, protein, starch and oil contents in grain of maizeinbred lines, Genetika, vol. 46, no. 1, pp. 243-253, Društvo genetičara Srbije, Beograd.

15. Jovanović, Z., Stikić, R. (2012): Strategies for Improving Water Productivity and Quality of Agricultural Crops in an Era of Climate Change, In book: Irrigation Systems and Practices in Challenging Environments, Ed., Teang Shui Lee, InTech., pp. 77-102, Rijeka, Croatia.

16. Kendall, C., Dejonge, A.L.K. and Kaleita, K.R.T. (2007): Simulating the effects of spatially variable irrigation on corn yields, costs, and revenue in Iowa, Agricultural Water Management, Elsevier Ltd., vol. 92, pp. 99-109, Amsterdam, Netherlands.

17. Kresovic, B., Matovic, G., Gregoric, E., Djuricin, S and Bodroza, D. (2014): Irrigation as a climate change impact mitigation measure: Anagronomic and economic assessment of maize production in Serbia, Agricultural Water Management, Elsevier Ltd., vol. 139, pp. 7-16, Amsterdam, Netherlands.

18. Kuscu, H., Karasu, A., Oz, M., Demir, A.O. and Turgut, I. (2013): Effect of irrigation amounts applied with drip irrigation on maize evapotranspiration, yield, water use efficiency, and net return in a sub-humid climate, Turkish Journal of Field Crops, Ege University, Faculty of Agriculture, Department of Field Crops, vol. 18, no. 1, pp. 13-19, Konak-Izmir, Turkey.

19. Luquet, D., Vidal, A., Smith, M., Dauzat, J. (2005): 'More crop per drop': how to make it acceptable for farmers? Agricultural Water Management, Elsevier Ltd., vol. 76, pp. 108-119, Amsterdam, Netherlands.

20. Abd El-Waheda, M.H., Ali, E.A. (2013): Effect of irrigation systems, amounts of irrigation water and mulching on corn yield, water use efficiency and net profit. Agricultural Water Management, Elsevier Ltd., vol. 120, pp. 64-71, Amsterdam, Netherlands.

21. Maksimović, L., Joćković, D.J., Dragović, S. (2004): Gajenje kukuruza u navodnjavanju značajan činilac unapređenja i stabilnosti proizvodnje, Zbornik radova, Sveska vol. 40, pp. 257-268, Naučni Institut za ratarstvo i povrtarstvo Novi Sad.

22. Matović, G., Broćić, Z., Đuričin, S., Gregorić, E., Bodrož, D. (2016): Profitability assessment of potato production applying different irrigation methods, Irrigation and Drainage, Wiley Online Library, vol. 65, pp. 502-513, Hoboken, New York, USA (DOI: 10.1002/ird.1983).

23. Nagaz, K., Masmoudi, M.M., Mechlia, N.B. (2007): Soil salinity and yield of dripirrigated potato under different irrigation regimes with saline water in arid conditions of Southern Tunisia. Journal of Agronomy, vol. 6, pp. 324-330, Asian Network for Scientific Information.

24. Peralta-Videa, J.R.; Lopez, M.L.; Narayan, M.; Saupe, G., Gardea-Torresdey, J. (2009): The biochemistry of environmental heavy metal uptake by plants: 
Implications for the food chain, The International Journal of Biochemistry and Cell Biology, Elsevier Ltd., vol. 41, no. 8-9, pp. 1665-1677, Amsterdam, Netherlands.

25. Perez-Perez, J.G., Garcia, J., Robles, J.M., Botia, P. (2010): Economic analysis of navel orange $\mathrm{cv}$. 'Lane late' grown on two different drought-tolerant rootstocks under deficit irrigation in South-eastern Spain, Water Management, Elsevier Ltd., 97, 157-164, Amsterdam, Netherlands.

26. Savić, S., Stikić, R., Zarić, V., Vucelić Radović, B., Jovanović, Z., Marjanović, M., Djorđević, S., Petković, D. (2011): Deficit irrigation technique for reducing water use of tomato under polytunnel conditions, Journal of Central European Agriculture, vol. 12, no. 4, pp. 597-607, Agricultural University Plovdiv, Plovdiv, Bulgaria.

27. Stikic, R., Zaric, V., Vucelic-Radovic, B., Jovanovic, Z., Stricevic, R., Markovic, N., Ruml, M., Petkovic, D. (2011): Deficit irrigation method for reducing water use of grapevine, Acta biologica Iugoslavica - serija A - Zemljište i biljka, vol. 60, no. 1, pp. 15-24, Unija bioloških naučnih društava Jugoslavije, Beograd.

28. Petrović, I., Marjanović, M., Ćosić, M., Savić, S., Cvijanović, G. (2016): Infra-red thermography for detecting drought in agricultural crops and scheduling irrigation. Economics of Agriculture, no. 2, pp. 461-470, Institute of Agricultural Economics, Beograd.

29. Surdyk, N., Cary, L., Blagojevic, S., Jovanovic, Z., Stikic, R., Vucelic-Radovic, B., Zarkovic, B., Sandei, L., Pettenati, M., Kloppmann, W. (2010): Impact of irrigation with treated low quality water on the heavy metal contents of a soil-crop system in Serbia. Water Management, Elsevier Ltd., vol. 98, no. 3, pp. 451-457, Amsterdam, Netherlands.

30. Vukelić, G. , Đuričin, S. (2012): Agricultural output growth at the regional level in Serbia, Managing structural changes: trends and requirements. Faculty of Economics of the University of Coimbra, pp. 611-626.

31. Younis, S.M., Shiboon, M.A., Aref, A.O. (1991): Evaluation of some mechanical methods of rice production in Egypt, Misr Journal Of Agricultural Engineering, vol. 8, pp. 39-49, Misr Society of Agricultural Engineering, Egypt. 


\title{
POSLEDICE KLIMATSKIH PROMENA NA MENADŽMENT VODA U POLJOPRIVREDI: IZAZOV ZA POVEĆANJE PRODUKTIVNOSTI USEVA U SRBIJI
}

\author{
Sonja Đuričin ${ }^{6}$, Slađana Savič ${ }^{7}$, Duško Bodroža ${ }^{8}$, Gorica Cvijanovič \\ Slaviša Đorđevicí ${ }^{10}$
}

\begin{abstract}
Sažetak
Godine obuhvaćene istraživanjem, shodno srednjim dnevnim temperaturama vazduha $i$ sumi padavina, odlikovala je učestala pojava sušnih i ekstremno toplih vegetacionih perioda. Cilj istraživanja je ocena ekonomske isplativosti proizvodnje kukuruza, krompira i paradajza u uslovima FI. Ocena ekonomske isplativosti primene sistema za navodnjavanje u slučaju proizvodnje kukuruza i krompira izvršena je na osnovu komparativne analize ostvarenog profita u prirodnom vodnom režimu i FI, dok u slučaju plasteničke proizvodnje paradajza izvršena na osnovu komparativne analize profita ostvarenog u uslovima RDI i FI. Rezultati istraživanja ukazuju na pozitivan ekonomski efekat primene sistema za navodnjavanje jer u našim klimatskim uslovima kulture svoje potrebe za vodom ne mogu da zadovolje isključivo padavinama, te se tako javlja deficit vode. Upravo taj nedostatak padavina uslovljava redukciju prinosa kao glavnog parametra u povećanju profitabilnosti proizvodnje i iz tog razloga bi povećanje površina pod sistemima za navodnjavanje bilo izuzetno značajno.
\end{abstract}

Ključne reči: klimatske promene, produktivnost useva, krompir, paradajz, kukuruz.

6 Dr Sonja Đuričin, Naučni saradnik, Institut ekonomskih nauka, Ulica Zmaj Jovina br. 12, 11000 Beograd, Srbija, Telefon: +381 63843 8896, E-mail: sonja.djuricin@ien.bg.ac.rs.

7 Vanredni profesor, dr Slađana Savić, Džon Nezbit Univerzitet Beograd, Fakultet za biofarming, Bačka Topola, 24300 Bačka Topola, Ulica Maršala Tita br. 39, Srbija, Telefon: +381 604434615, E-mail: bonita.sladja@gmail.com.

8 Dr Duško Bodroža, Istraživač saradnik, Institut ekonomskih nauka, Ulica Zmaj Jovina br. 12, 11000 Beograd, Srbija, Telefon: +381 64514 7136, E-mail: dusko.bodroza@ien.bg.ac.rs.

9 Redovni profesor, dr Gorica Cvijanović, Džon Nezbit Univerzitet Beograd, Fakultet za biofarming, Bačka Topola, 24300 Bačka Topola, Ulica Maršala Tita br. 39, Srbija, Telefon: +381692406 036, E-mail: cvijagor@yahoo.com.

10 Dipl. inž. Slaviša Đorđević, istraživač saradnik, Univerzitet u Beogradu, Poljoprivredni fakultet, Beograd - Zemun, Nemanjina ulica br. 6, Srbija, Telefon: +381 621120 447, E-mail: djslavisa@agrif.bg.ac.rs. 